\title{
How to reconcile work and university studies - An action research case from Finland
}

Satu Kalliola, Jukka Niemelä and Ossi Eskelinen

\begin{abstract}
University traditions are confronted by continuous global competition and are challenged to provide more and faster highly educated labor force. On the other hand, many adult students work along their studies which prolong earning their degrees. The study explores the perspectives of employers and students, teachers and student advisors coming from two University Consortia, on the need to reconcile work and studies and on the potential practices to do that. The research setting is that of Action Research applying Democratic Dialogue. The study examines the dialogues of all participant groups, action plans made, practical outcomes after five years of a dialogue based intervention and the learnings about the method used. The study concludes that instead of studyfriendly practices at the workplaces, the universities are adopting workfriendly practices, including e-learning, to support their students. The dialogue based method proved to be malleable enough to capture the diverse ideas of participants.
\end{abstract}

Keywords: Democratic Dialogue, action research cycle, adult students, reconciling work and studies

\section{Introduction}

The traditions of higher education institutions are confronted in many ways by continuous global economic competition. Higher education institutions are expected to contribute to the improvement of the competitive edge of nations. This claim is supported for example by the expansion of higher education, providing more qualified workforce although the rapid changes in the economy challenge the notion of qualifications leading to lasting careers (Brooks \& Everett, 2009). Also, the transformation of universities in Europe, and worldwide, towards the entrepreneurial university (Sam \& van der Sijde, 2014) is one aspect of higher education contributing to the national economic growth. However, also other perspectives have been presented. Kauppinen (2012) argues that emergent collaboration between transnational corporations and research universities gives rise to intermediate organizations and that these 
phenomena challenge the notion of the universities as being primarily promoters of national economic competitiveness.

In Finland, there exist also more levels of economic competition, namely regional and local. University Consortia are one way to take part in this competition. They are network organizations that bring academic activities of their region together and cooperate with regional and local actors. In their efforts to accelerate economic growth, and in some cases also in internationalization, their main asset is raising the level of education. Some of them offer bachelor and doctoral level education, although the emphasis is on the Open University studies and continuing education in the form of master's degree programs catered to mature-age students. (University Consortia, 2013) As many of them have families and full-time jobs when enrolling in further study, the issues of students working are among important topics discussed at the Finnish University Consortia.

It is hardly an overstatement that higher education institutions are expected to give their input also to the lengthening of working careers which is seen as a must in the ageing western societies. This presents a task to prevent the prolonging and abandoning of studies (Mäkinen, Olkinuora \& Lonka, 2004) and to accelerate the speed of earning a degree, leading to early entry into the labour market. In the debate on education policy in Finland, where there are no tuition fees in higher education, student employment has been suggested to be one of the main reasons why students prolong their studies (Saari, Mikkonen \& Vieno, 2013).

Although dependent on the cycles of the economy and the fluctuating demand of a highly educated labor force, the final decision to complete, or not complete, studies are made by students individually. Encouragement, and 
sometimes pressure, to enforce these decisions, may take place in the form of new legislation and government level steering, followed by university level development activities and projects, and by study-friendly practices of the employers. They could resemble family-friendly practices recommended by the Organization for Economic Co-operation and Development (OECD). The family-friendly practices may include a large selection of arrangements regarding work and working hours or situation-bound flexibility (OECD Family Database). Respectively, the study-friendly practices, supported by study-friendly organization culture, could contain many type of working time arrangements, human resource practices in study leaves, and rewards after the completion of studies as well as fair rules and instructions at a workplace.

The context of this study is one publicly funded project that aimed to accelerate the completion of studies at two university consortia. The objective of the study is to shed light on the perspectives of adult learners, their teachers and student advisors as well as the representatives of employers of the need, possibilities and means to reconcile university study and work. Also the setting of the study, an application of Democratic Dialogue (Gustavsen 1991; Gustavsen, 2001) in Dialogue Workshops is under investigation.

\section{The research background and development initiatives}

Some Finnish universities are members in more than University Consortium. This is the case of University Consortia A and B (UCA and UCB) that from time to time work together. UCA has an active Student Association (SA), which is a member of The National Union of University Students in Finland, the main interest organization for student grants and new developments in higher education policies. Already in 2007, SA, together with Students' Wellbeing Taskforce, had initiated Students' Wellbeing Survey (reported by 
Salonen \& Suntila, 2008) and invited the authors to assist in reflecting on required action to alleviate the problems revealed. Two findings were chosen for further reflection and workshops applying Democratic Dialogue (Gustavsen, 2001) were organized to address the wellbeing problems of the first year students ("Supporting the students in the beginning of their studies", and the students' perspectives on their future working life and careers in the region ("To stay on the region or to leave").These were reported together as Dialogue Workshops DW2008 to the participants. The survey resulted also in a notion that a significant part of the first year students were actually adult learners with practical problems in the reconciliation of studies, family and work (Salonen \& Suntila, 2008). This aspect was included in a European Social Fund project "Networked Skill Creation - Collaboration between University and Working Life in Accelerating Academic Studies" involving both UCA and UCB in 2009 - 2012 and led by one the member university of UCA. Adult Students' Wellbeing survey was included in the project in 2011 and again, SA and Students' Wellbeing Taskforce collaborated with the authors to organize in 2012 a Dialogue Workshop that is to be analyzed more closely.

\section{Democratic Dialogue combined with Lewinian Action Research Cycle in Dialogue Workshops}

As mentioned above, the student actors of UCA wanted to try how action research (AR) could contribute to their situation. This is a practical notion in our era of realizing societal aims by development programs and projects. The practicality of AR refers to its two fold role as a means to conduct interventions whilst simultaneously gathering data. The AR approach used in this research is a combination of the classic Lewinian Action Research Cycle ARC (1948) and the continuously evolving Nordic model of dialogue based methods of workplace innovation (Gustaven \& Engelstad, 1986; Gustavsen 1991; 
Alasoini, 2008; Gensby, 2014). Dialogue aspect is seen as a mean to enhance the value orientation of action research as well as wide participation of those concerned. It may transform the Lewinian Action Research Cycle from "social engineering”, as Lewin (1948) himself puts it, towards participatory action research, PAR (Reason \& Bradbury, 2001) and also towards normative planning and normative action research, characterized by the involvement of stakeholders, and advocated for example by Baburoglu and Ravn (1992).

All phases of the action research cycle (diagnosis of the problem to be solved as a basis for the future to be created, initiating action, evaluating the effects of the action and taking new action) can be carried out in a participatory and dialogical manner in cooperation with concerned parties, including stakeholders from other organizations. Forms of AR that deploy dialogue forums, such as Dialogue Conferences, were adopted to Finland from other Scandinavian countries. They have been used for example in Finnish municipalities since 1991 (Kalliola \& Nakari, 1999) and are often called as Work Conferences. According to the basic design of Dialogue Conferences, they are conducted as an interplay of dialogues in small groups and plenaries, and the participants are advised to follow the criteria of Democratic Dialogue (Gustavsen \& Engelstad, 1986; Gustavsen, 2001). Dialogue is differentiated from discussion by emphasizing a two-way communication, a matter of giving and taking, and by the objectives to generate and to concretize potentials for joint action (Gustavsen, 2001). From a pragmatic point of view it is a matter of expressing one's perspectives, based on personal work experience, listening, being heard, learning from others, and changing words into action (Kalliola, Nakari \& Pesonen, 2006; Kalliola, 2009).

As Democratic Dialogue firstly aims to give a voice to all stakeholders, and secondly, to gather these voices together to obtain an understanding of how the 
connections between relevant factors are viewed by the stakeholders, there exist a possibility of the theory of organization becoming local (Gustavsen, 1991; Elden, 1983). Weick (1995) refers to this type of reasoning as sense making in organizations. Getting to know how an organization is perceived by all stakeholder groups can foster a local theory of change. A researchers' input to this process would be that of theoretical knowledge and of governing a change process that would help to conceptualize the present as well as the desired future of the organizations in question. In the evolving practice of dialogue based AR, the role of the researchers has often been that of facilitators.

In UCA \& UCB setting the conduct of Dialogue Conferences had to be minimized to half a day and were therefore called Dialogue Workshops. In the program the design of dialogue conferences (Gustavsen \& Engelstad, 1986) was constrained by limited time and was adapted to the following phases: a presentation of the results of Adult Students Well-being Survey, dialogues based on these results and possible action planning, plenaries, and a closing discussion. The title "The added value of studying employees: Are they assets/special resources of their employers?" was formulated by SA and the authors to attract especially the interest of employers, who were invited among the alumni and private and public organizations recruiting students as their practical trainees. The invitation included the program of the workshop, a briefing about the method and the criteria for Democratic Dialogue.

Twenty-six individuals responded positively and participated in the workshop in February 2012. Their grouping was based firstly on genuinely homogenous position of being either a student, a teacher, a student advisor or an employer. The second dialogues were conducted in branch specific groups of Business, Creative Business, Public Services and Technology. 
The groups were advised to elect a secretary to summarize the dialogues on overhead projector slides/flip board paper and a presenter to convey the main points to the other groups in a plenary to follow. For further studies, the dialogues were tape recorded by resource persons who were prepared to take notes, in case of technological problems. The researchers visited all the groups reminding of the application of Democratic Dialogue. The researchers documented the inputs given in the plenaries and closing discussion to the field notes. All the presented documents of the Workshop were compiled in their original form to a protocol type of report (DW2012) that was delivered to all participants and the organizers.

\section{Defined research questions, data, analysis and reporting in ARC framework}

The main interest of this study lies in the Dialogue Workshop "The added value of studying employees: Are they assets/special resources of their employers?" and the contributions of it to the participants, when viewed and evaluated in retrospect, after five years, and to further the understanding of the application of Democratic Dialogue in small scale workshops. Defined research questions rise from the theme of Dialogue Workshop in 2012 and the method applied.

Thematic analysis:

1. What was the overall theme of the experiences of the UCA and UCB students with respect to the relationship between study and work as assessed by the Adult Student Wellbeing Survey?

2. How did the various stakeholder groups interpret the theme(s) in the 2012 Dialogue Workshop? What were the similarities and the differences in the 
main concerns of the various groups in the matter of reconciling studies and work?

Action plans:

3. Were there any shared initiatives established that could be further developed in the 2012 Dialogue Workshop?

Follow-up and learning from evaluation:

4. What initiatives of the 2012 Dialogue Workshop were carried out and acted upon and why?

5. What could be learned about the AR method?

In order to derive answers to the research questions, diverse data is combined to construct a comprehensive interpretation of the AR approach used in UCA and UCB development initiatives.

Data from Adult Students Well Being Survey data in 2011 was analyzed mainly by cross tabulations (labor market position of the students as the independent variable) and tested by $\chi^{2}$-test as mainly statistically significant $(\mathrm{p}<0,05)$. The main conclusions of cross tabulations are presented in the section of Diagnosis and are followed by group dialogues interpreting their practical meaning to the participant groups. The report of Students' Well-being Survey in 2007 (Salonen \& Suntila, 2008) is referred as background information.

The ARC based report continues by presenting the action planning phase both in dialogues and closing discussion and proceeds towards evaluation. Data consists of Dialogue Workshop Reports (DW2008 and DW2012) and the Final Report of ESF-project “Networked Skill Creation ...” (ESF 2013). These are protocols, compiled in Finnish, containing no interpretations, and are used along the researchers' field notes to secure the chronological presentation of 
the events belonging to the ARC. The data used in the evaluation comes from current websites of the member universities of UCA and UCB and from the researchers' observations.

As Dialogue Workshop in 2012 is the main intervention under investigation, the original documentation of all group dialogues and plenaries were translated into English. The qualitative analysis was a combination of theme based and data-driven approach (Ylijoki \& Mäntylä 2003). The theme based analysis was guided by the research questions and proceeded from dialogue assignments towards group specific perspectives. The data driven approach allowed some new aspects to emerge in the results. All the other data was analyzed in the Finnish language and translation took place only when needed in constructing this article.

The Action Research Cycle of Dialogue Workshop "The added value of studying employees: Are they assets/special resources of their employers?”

\section{Diagnosis}

The 2007 Students' Well-being Survey (Salonen \& Suntila, 2008) emphasized the difficulty adult students have reconciling the different spheres of their lives, especially with respect to working and studying. Nevertheless, one of the main findings was that for students over 40 years old, studying was an important resource, not a source of stress; they reported hardly any health related symptoms connected to their studies, no feelings of loneliness, and reported that the Region was a pleasant place to live and they were satisfied with their income. In the Adult Students' Wellbeing Survey (2011), the items were formulated more deeply to assess core issues in studying, working and family 
life. In the opening of the subsequent Dialogue Workshop (2012), the results of the new survey were presented as slides to the participants. In addition to the results concerning work and studies, some family life variables were covered from the point of view of conflicts and stress (reported in Finnish by Niemelä, 2014).

Altogether 363 students filled the questionnaire that was available both in electronic and paper format. The response rate is impossible to count since the universities do not gather information about their students' labor market and marital status.

The major part of the respondents (40\%) were working full-time, 17\% were working part-time and $17 \%$ on leave from work, leaving the remaining $26 \%$ as full-time students. Also the majority of all respondents (67\%) felt that studying was the most neglected sphere of their life. Students working fulltime reported that their time spent studying averaged 17 hours and working 37 hours each week. When asked for the main reason that they did not spend more time studying, $67 \%$ of students working full-time reported it was their work.

The responses to questions about the importance of these two areas of life, work and studies, were the following:

Most of the students working full-time found the role of their work to be of significant importance (75\%) and felt very committed to their present work (73\%) while over half of students engaged in part-time work or on leave from work felt that their work merely served to provide a daily income. Additionally, the joy and fulfilment derived from work was more heavily reported among the students engaged in full-time work over the other groups. In accordance, with students working full-time reportedly valuing the role of work in their 
lives highly, the role of studying was valued less than that of the other groups. Conversely, over half of students engaged in part-time work agreed that study was the most important thing in their lives. When asked to consider what areas outside of work are most heavily compromised by studying, participants reported strongly other areas than work: household duties (52\%), free time (51\%), exercise or outdoor recreation (47\%), and family relationships (44\%).

Students working full-time really do this, since $84 \%$ of them study totally on free time from work whereas majority of the students working part-time (71\%) have an official part-time working contract because of their studies. On the other hand, students working full-time have a higher level of arrangements to study during the regular working day than students working part-time, which corresponds with the type of their contracts. They may be allowed to leave the work place in the middle of the regular working day, start working later than the regular working day starts or to leave work earlier than the regular working day ends, take whole days as free, and change bonus holiday pay for days off. As a whole, the contents of the agreements between the employers and the working students seem to be diverse. The agreements form the basis to support reconciling work and studying, and represent thus examples of study-friendly practices at the workplace.

According to the principles of Democratic Dialogue PAR the organizers of the workshop did not emphasize any of the results presented over the others. The short plenary discussion made two conclusion: 1.Although studying is recognized as an important part of the students' lives, it is often also the most neglected area in the lives of employed students. 2 . The students connect with their employers and their universities, but the latter two do not meet. (Researchers' notes.) 
The questions to be reflected in the first group dialogue were the following: Do the results of Adult Students Wellbeing Survey constitute a problem and do we need to solve it? What are the needs and hopes of various actor groups when considering the issue of reconciling studies and work? What would be the desirable future of reconciling studies and work? The results of the dialogues by homogenous groups are presented in Figure 1.

\begin{tabular}{|l|l|}
\hline Homogenous Group (n) & Students (8) \\
\hline Needs and Hopes & Flexibility in Studies, Working life and Family life \\
\hline $\begin{array}{l}\text { Elements of Desirable } \\
\text { Futures }\end{array}$ & $\begin{array}{l}\text { Web, compensation of absences, diverse ways to } \\
\text { take courses } \\
\text { Positive attitude of the employer } \\
\text { = Flexible arrangements will take place } \\
\text { Optimal choices }\end{array}$ \\
\hline $\begin{array}{l}\text { Prerequisites and / or } \\
\text { Constraints }\end{array}$ & $\begin{array}{l}\text { Motivation to study must be strong, since it is a } \\
\text { matter of giving up one's personal life } \\
\text { Listening to only good advice }\end{array}$ \\
\hline
\end{tabular}

\begin{tabular}{|l|l|}
\hline Homogenous Group (n) & Employers (6) \\
\hline Needs and Hopes & $\begin{array}{l}\text { Flexibility } \\
\text { Theoretical vs. Practical knowledge } \\
\text { Transfers: from studies to work and from work to } \\
\text { studies } \\
\text { Openness; Interaction; Internationalization }\end{array}$ \\
\hline $\begin{array}{l}\text { Elements of Desirable } \\
\text { Futures }\end{array}$ & $\begin{array}{l}\text { Hours spent in studies could be corresponded with } \\
\text { Working hours. } \\
\text { Continuous learning is called for. } \\
\text { An adult learner is more open for new ideas. } \\
\text { Sharing the profits (gains) of studies } \\
\text { Getting familiar with other cultures } \\
\text { Prerequisites and / or } \\
\text { Constraints }\end{array}$ \\
$\begin{array}{l}\text { Needed both form the employer and the university } \\
\text { Field of studies counts } \\
\text { Adult learners are more open to new ideas. } \\
\text { Students' commitment to their jobs } \\
\text { Organization culture counts } \\
\text { This is a "must”. }\end{array}$ \\
\hline
\end{tabular}

Homogenous Group (n) Teachers (6) 


\begin{tabular}{|c|c|}
\hline Needs and Hopes & \\
\hline $\begin{array}{l}\text { Elements of Desirable } \\
\text { Futures }\end{array}$ & $\begin{array}{l}\text { Students having jobs enrich the communities of } \\
\text { studying } \\
\text { Students' attitudes: most are very motivated }\end{array}$ \\
\hline $\begin{array}{l}\text { Prerequisites and / or } \\
\text { Constraints }\end{array}$ & $\begin{array}{l}\text { Contact teaching is planned for full time students } \\
\text { Studying is supposed to be the number one priority } \\
\text { in the life of a university student } \\
\text { The pace of studies is low } \\
\text { Learning at work is not taken into account } \\
\text { Compensating absences = extra work load } \\
\text { There exists only little e-teaching } \\
\text { Students' attitudes: part of the students want only } \\
\text { formal qualifications } \\
\text { Students' expectations: (High) Standard of living, } \\
\text { Hígh quality of teaching (expressed especially by } \\
\text { students having a job) }\end{array}$ \\
\hline
\end{tabular}

\begin{tabular}{|l|l|}
\hline Homogenous Group (n) & Student Advisors (6) \\
\hline Needs and Hopes & Flexibility \\
\hline $\begin{array}{l}\text { Elements of Desirable } \\
\text { Futures }\end{array}$ & $\begin{array}{l}\text { Equality must prevail } \\
\text { Students take the responsibility of their studies }\end{array}$ \\
\hline $\begin{array}{l}\text { Prerequisites and / or } \\
\text { Constraints }\end{array}$ & $\begin{array}{l}\text { Limits to flexibility: } \\
\text { The provider of the education should not allow too } \\
\text { much variation in the modes to earn study points } \\
\text { within one course or curriculum } \\
\text { Students acquire relevant information and plan } \\
\text { their studies and and the degree of } \\
\text { Attitude, motivation and the } \\
\text { commitment to studies are crucial }\end{array}$ \\
\hline
\end{tabular}

Figure 1. Diagnosis based on the Adult Students Well-being Survey by homogenous groups

In the students' responses were references to the quality of life as a whole, as interpreted from the diverse, and also conflicting time perspectives of academic work by Ylijoki and Mäntylä (2003). The encouragement to make optimal choices corresponds with the timeless time, referring to internally motivated and self-controlled use of time, and to personal time (referring to one's temporality and the roles of studies, work and families in it). The other time perspectives are scheduled time (working according to externally imposed and controlled timetables) and contracted time, featuring a sense of time as 
something that is terminating combined with an uncertainty about the future. (Ibid.)

The teachers' position seems to be almost in a total opposition towards the needs and hopes expressed by the students. The teachers were the only group that actually presented no visions of a desirable future about the issue under discussion, but rather saw any changes as constraints to keep things as they used to be. In fact, the teachers’ presentation appeared to defend the traditional university model - that in Finland used to be Humboldtian (Sam \& van der Sidje, 2014) - and also the traditional working conditions of the teachers against the new demands.

When interpreting that having a job is for students a mean to keep up a certain standard of living, the teachers might be right. In their research on the subsistence of tertiary students in different life situations Mikkonen, Lavikainen \& Saari (2013) have shown that taking out a student loan is the clearest indication of a low level of subsistence, whereas employment is a predictor of a high level of subsistence. According to the above mentioned research, students who have taken out a student loan find that the loan has advanced their academic progress only marginally. Further, the students see a loan primarily as a solution to problems of time management and only secondly to problems that pertain to subsistence. On the other hand, adult students seem to take study leaves, or sabbaticals, quite seldom and prefer organizing their lives without the support of adult students' grants. However, parallel to the teachers' interpretation about the significance of jobs in delivering steady income there is the realm of jobs as a significant meaning of life. 
The student advisors took their position as mediators between the opposing needs of the students and the teachers. The emphasis on equality can been seen as an important criterion of the outermost limit of flexibility.

The employers' perspective can be interpreted at the same time as that of a proactive leader (interaction and internationalization needed) and of a cautious human research manager (what type of knowledge is needed; is a studying student worth the costs?). The idea of the shared flexibility between the employers and the university can be seen as one example of negotiation result, typical for the labor market bargaining.

In the plenary unanimity of the significance of the students' motivation to study and the need of flexibility were emphasized, although the teachers presented the latter only as an expectation of the students. The current status of the university as "a regular day time organization” was seen as a basic kind of a problem to be solved on the way towards flexibility. (Researchers' notes.)

The branch specific group discussions are summarized in Figure 2.

\begin{tabular}{|l|l|}
\hline Branch Croup (n) & Creative Business (6) \\
\hline Immediate Action & Ground rules to be communicated to the students \\
\hline Future Action & $\begin{array}{l}\text { More contact teaching in the evenings and during the } \\
\text { weekends and more diversity in the modes to take } \\
\text { courses } \\
\text { More contacts between the university and the employers }\end{array}$ \\
\hline Constraints & $\begin{array}{l}\text { Enhanced flexibility increases the need for new resources } \\
\text { The employers do not recognize the added value of their } \\
\text { studying employees } \\
\text { Greater support needed from the society (better students } \\
\text { grants) } \\
\text { Greater support needed from the employers }\end{array}$ \\
\hline
\end{tabular}

Branch Croup (n) Business (6) 


\begin{tabular}{|l|l|} 
Immediate Action & $\begin{array}{l}\text { The students must be the most flexible part of the } \\
\text { equation in reconciling studies and work } \\
\text { Improving student counselling }\end{array}$ \\
\hline Future Action & $\begin{array}{l}\text { More courses on-line and as Open University modules in } \\
\text { the evenings } \\
\text { No permanent jobs to students before the completion of } \\
\text { studies; raise in the pay after the Master's degree }\end{array}$ \\
\hline Constraints & \\
\hline
\end{tabular}

\begin{tabular}{|l|l|}
\hline Branch Croup (n) & Technology (7) \\
\hline Immediate Action & $\begin{array}{l}\text { More information: } \\
\text { Ground rules to be communicated to the students } \\
\text { More flexibility: } \\
\text { E-learning and Moodle }\end{array}$ \\
\hline Future Action & $\begin{array}{l}\text { The best potential of interaction, "the flavor" of contact } \\
\text { teaching is missed on-line } \\
\text { Doubts about the successful transfer of the students' } \\
\text { responsibilities to "the home atmosphere" }\end{array}$ \\
\hline Constraints
\end{tabular}

\begin{tabular}{|l|l|}
\hline Branch Croup (n) & Public Services (7) \\
Immediate Action & $\begin{array}{l}\text { Teaching Schedules to be published as early as possible, } \\
\text { which paves the way to the use of Flexitime } \\
\text { The recognition of earlier studies should be made clear } \\
\text { in the very beginning of the studies } \\
\text { City of X practice: two days per month free for students } \\
\text { studying to be qualified social workers }\end{array}$ \\
\hline Future Action & $\begin{array}{l}\text { The practice may not hurt the rights of flexibility of non- } \\
\text { studying work force; the practice is too dependent on the } \\
\text { demand of qualified social workers; in case of } \\
\text { oversupply no free time allowed }\end{array}$ \\
\hline Constraints
\end{tabular}

Figure 2: Summary of branch specific action plans.

In the branch specific dialogues no clear differences between Creative Business, Business, Technology and Public Services could be traced. Conversely, the groups were similar in their attitude to demand nothing from the employers. Only Business presented the idea of graduation as a prerequisite for permanent jobs and also lower pay before graduation. This practice would affect mostly the students themselves, not the employers, and would not be applicable in cases, where the students work permanently in branches differing 
from their studies. Altogether, the emphasis was on flexibility and student counselling. Despite this unanimity the plenary discussion was vivid. Topics like a true need to strengthen the connections between the employers and the society as a whole and enhanced student counselling as a necessity in delivering the message of the demands of studying at a university. (DW 12; Researchers' notes).

The students furthered their discussion on optimal choices presented in the first dialogue, addressing the idea of study as a privilege and as an opportunity to learn new things. It may be that the students were more likely to use their own time for studies. In the frame of reference of the diverse time perspectives of academic work (Ylijoki \& Mäntylä, 2003), this can be interpreted as a delight of getting immersed in their studies.

The presentation of Creative Business was discussed further from the teachers' perspectives: 1) the diversifying of the schedules and ways to complete courses will require more resources to the universities, 2) the more ample student grants might help to keep up "the regular daytime organization”.

Also the Public Sector presentation aroused some new perspectives: 1) the students may not want their employer to support their studies since they do not want to get tied to a single employer, 2) the employers had generally broken the earlier social/collective and psychological/individual contracts that had maintained the employees' loyalty and 3) many students see studying new things as a privilege and do not want to get all the parts of the curricula to be compensated by earlier studies or knowledge.

Planning the action: closing discussion and emergent action plans 
In the closing discussion, the participants expressed no need to return to the theme of the extra resources originally emphasized by the teachers and, later, the Creative Business group; this also neglected the students' demand for more diverse teaching schedules and the opinion of Business group that obliged the students themselves to be the most flexible partner. Instead, the latter idea was adopted in a milder formulation with securing the motivation and responsibility of the students themselves presented as one of the action steps to be taken. Parallel to that, the communication of the ground rules kept its place as an important activity, acting as a mediating practice between the perspectives of the students desires for increased flexibility, and the teachers desires to keep the things as they were; it is also a practical implication of the student advisors' perspective of stressing a moderate way to be flexible. The other activities to be taken included the improvement of student counselling, the development of e-learning, and building more contacts between the universities and the employers. (DW2012, 9-10.)

The development of e-learning, presented many times during the dialogues, was most strongly supported by an UCB representative, stressing the good experiences they had after transforming a significant part of teaching to take place either on-line or in the evenings as Open University teaching modules. E-learning was seen as a future option, but teaching in the evenings and the Open University option did not gain favor, once again due to the teachers' position.

The more specific lines of actions agreed were the following: 
- $\quad$ New students will be informed immediately after their admission about the demands of university studies, which challenges them to make choices based on genuine motivation.

- $\quad$ Admitted students will get this information prior to making a decision on acceptance of their program offer.

- $\quad$ All courses and all assignments must be taken and accomplished with passing grades.

- After communicating the ground rules, the securing of motivation and responsibility belongs into the spheres of academic counselling and study advisors, who will take part in the Personal Study Plan (PSP) process discussing the individual aims of each student and concrete means to attain them.

- $\quad$ The students will be supported in many ways in their efforts to combine a personalized "puzzle" or "mosaic" consisting of their studies, work and other life, centring very often around a family.

The interpretation given to academic counselling and PSP was that of an agreement between the student and the university community. Following Ansela, Haapaniemi \& Voutilainen (2005), PSP was seen to alleviate the anxiety caused by the academic freedom, the amount of which may be experienced as excessive, to motivate, to lay down certain obligations and to enhance commitment to studies.

In addition, some fragile ideas of working life connections were presented and supported: 
- $\quad$ The recruitment services of universities could take part in PSP updates with the students' working life orientation and professional interests taken into account in new plans to promote their knowledge and skills.

- With the permission of the students, the study advisors could contact employers, with whom the necessary flexible working hour arrangements could be discussed.

- Employers could be asked to contribute to the practices of the recognition of prior learning, based on their exact knowledge concerning the students.

In addition to the above mentioned notions, no other ideas concerning the employers' future role or activities to be taken by them to create new practices in reconciling studying and working were presented. All in all, in the closing discussion it became obvious that there is a long way to go in this matter to reach study-friendly practices at the workplace in addition to agreements covering working hours. The further development of the working life connections were transferred to the "Networked Skill Creation" -project.

\section{Taking the action}

The teachers and students advisors had to adapt the concrete ideas agreed upon in the workshop with the daily practices of their universities and found potential to realize the ideas. However, six months after the Dialogue Workshop the “Networked Skill Creation” project decided to continue along more traditional lines in employer - university collaboration, and organized a panel discussion on the theme of the knowledge and skill challenges of the future working life (ESF Report 2013, 4). The project found it more purposeful to focus on the issues of the relevance of the university education and the steps 
to build the students' careers (Tomlinson 2007) than to continue the search for study-friendly practices at work. Thus, when reflecting on the activities agreed upon, they all belong to the duties of universities that will transform themselves from "regular daytime organizations" to work-friendly, flexible higher education institutions.

\section{Follow-up and explanations}

As a logical conclusion from the activities agreed upon in Dialogue Workshop in 2012, the role of the employers as such is missing in Figure 3 that lists the actions taken and actors by 2017 to reconcile work and studies at UCA and UCB.

\begin{tabular}{|l|l|}
\hline $\begin{array}{l}\text { Activity included in the action } \\
\text { plan }\end{array}$ & $\begin{array}{l}\text { Evaluation: What has been done and by } \\
\text { whom? }\end{array}$ \\
\hline $\begin{array}{l}\text { Securing the motivation and } \\
\text { responsibility of the students } \\
\text { themselves }\end{array}$ & $\begin{array}{l}\text { Personal motivation letters and } \\
\text { preliminary study plans may be required } \\
\text { when applying a position as a master's } \\
\text { degree student (the universities require; } \\
\text { the students apply) }\end{array}$ \\
$\begin{array}{l}\text { The communication of ground } \\
\text { rules }\end{array}$ & $\begin{array}{l}\text { Included in the admission letters (by the } \\
\text { universities) }\end{array}$ \\
\hline $\begin{array}{l}\text { Enhancing student counselling; } \\
\text { tied to the two above mentioned } \\
\text { activities }\end{array}$ & $\begin{array}{l}\text { Teachers are more and more involved in } \\
\text { student counselling and in the PSP - } \\
\text { processes while the student advisors role } \\
\text { is changing towards administrative issues } \\
\text { (details of curricula, certificates of } \\
\text { degrees); PSP updates more regularly (by } \\
\text { universities) }\end{array}$ \\
\hline $\begin{array}{l}\text { The development and applications } \\
\text { of e-learning on a regular basis }\end{array}$ & $\begin{array}{l}\text { “New Solutions to Support E-teaching } \\
\text { and E-learning at UCA”, 2016 and 2017 } \\
\text { (by universities) }\end{array}$ \\
\hline $\begin{array}{l}\text { Building more contacts between } \\
\text { the universities and the employers } \\
\text { More Open University teaching } \\
\text { modules and evening classes } \\
\text { No permanent jobs to students } \\
\text { before the completion of studies; } \\
\text { raise in the pay after the Master's } \\
\text { degree }\end{array}$ & $\begin{array}{l}\text { "Regional Learning Platform of Social } \\
\text { Sciences”, 2015-2018 (by universities) } \\
\text { University merged or merging; study } \\
\text { credits in Open University a budget } \\
\text { indicator since 2012 (by the Ministry of } \\
\text { Education and Culture) } \\
\text { New Act on Social Welfare Professionals } \\
817 / 2015 \text { together with the Act on }\end{array}$ \\
\hline
\end{tabular}




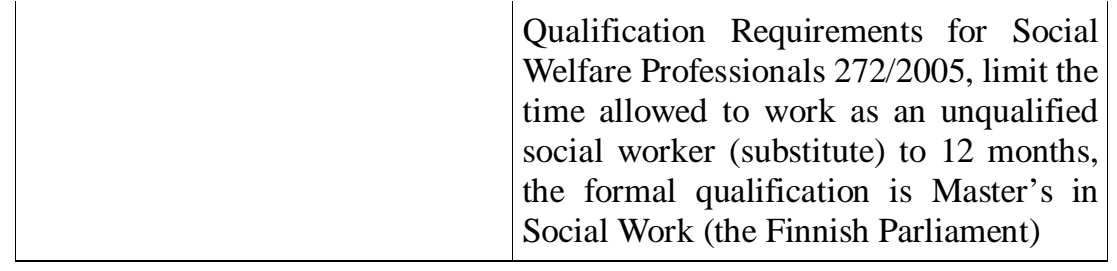

Figure 3: Summary of the practical outcomes and responsible actors.

The student advisors together with teachers have been busy to implement enhanced student counselling and PSPs. New projects have been established to respond to the needs acknowledged, one to support e-learning and one to support university - employer -relationships.

It is noteworthy that the Dialogue Workshop in 2012 did not define any specific means of e-learning, but rather accepted the myth of it as a universal tool to reach flexibility needed by working students. From the teachers’ perspective the issue is studied by Kukulska-Hulme (2012) who proposes a lifelong learning perspective which can help the higher education workforce to adapt to the forever changing technology. This view is worth noting since the vision of Keppell (2014) about the next generation learning spaces is about to come true. Keppell (2014) depicts learners to traverse physical and virtual spaces using personalized learning strategies involving for example digital citizenship, seamless learning, learner engagement, learning-oriented assessment and lifelong and life-wide learning. This might have a bearing also on the working students. "New Solutions to Support E-teaching and E-learning at UCA”-project seeks to find practical answers to these challenges.

The project enhancing cooperation between the universities and the employers, "Regional Learning Platform of Social Sciences”, funded by the European Regional Development Fund (ERDF), may be seen rather to continue the Dialogue Workshops Conference in 2008 concerned with the employment 
opportunities of the UCA graduates, or their employability (see Tomlinson 2007), than to create study-friendly workplaces. The main aim of the project is to build new type of connections between universities and working life. It builds partly on the traditional modules of practical training/internships, with the emphasis of learning at work, topics for thesis and continuing education, but it aims higher: The new ideas include, for example, interactive, joint workshops for degree students and graduates in continuing education; both parties learning from each other, creating new learning contents, recognizing prior learning, supporting students by mentoring with the help of alumni. It differs from the Networked Skilled Creation project in the aspect of students involved: now all students are invited to participate, not only those with prolonged studies and problems of graduation. (Plan/Manuscript of "Regional Learning Platform of Social Sciences”).

While in the Dialogue Workshop in 2012 increasing the number of study modules offered by Open University, together with more versatile teaching schedules; was not supported, five years later, this activity has gained a lot of favor. Some of member universities of UCA and UCB have integrated Open University into their regular teaching activities. The rationale behind this is financial: it is cheaper to use the same resources to implement both degree and non-degree programs. Also, if e-learning is available, it usually increases the credits obtained by all students. This is profitable, since in addition to the number of bachelors and masters' degrees, the Open University study credits as well as the number of students gaining more than 55 study credits in one year are among the new university performance indicators used in the allocation of basic funding (Decree by the Ministry of Education and Culture, 2012). O'Lawrence (2007) argues that reducing the cost of education is an obvious reason to enhance e-learning (as such, without ties to Open University), but is often publicly denied. 
The idea presented by Business Dialogue that no permanent job should be offered to students before graduation, is strongly alive in the sphere of social work. Within the framework of traditional university models (Sam \& van der Sidje, 2014) the recent Act on Social Welfare Professionals ( 817/2015) is in line with the Napoleonic, French model, that emphasizes high level vocational skills and professional education.

The compilation of actions taken on the basis of the dialogues and plans of the Dialogue Workshop 2012 seems impressive. However, when looking at them closely, we can hardly conclude that the ideal of using local knowledge (Elden, 1983) to create local action, would have taken place. Rather, the ideas were carried out due to external forces, although it would be quite challenging to measure exactly the impact of the action plans created, since the recent changes in curricula encourage, or force, more students than usually to get their degree completed. Another notion is that development projects created to meet every day challenges have kept their place.

\section{Learnings about the AR method applied}

The application of Democratic Dialogue in small scale workshops to vision and create concrete practice to reconcile work and studies was a method specific approach (Alasoini, 2008). The pragmatic idealism of Democratic Dialogue was transferred to an environment consisting of stakeholders with seemingly shared, but practically diverse goals and to episodic encounters in Dialogue Workshops, not in long lasting development work. Spontaneous feedback was good as detected in the atmosphere of the workshop. Feedback was gathered via an on-line questionnaire, but only five participants responded (ESF 2013, materials). The organizers learned, once again, that getting one's 
perspective to be heard is not very simple (Kalliola \& Nakari, 2007), and that people having studies, jobs and families organizes the time tightly.

"The discussion dealt mostly with young degree students, who have jobs in order to finance their studies; this happened in the second group. The working method was good and after some problems in the beginning, the discussion was vivid.“(Participant 1.)

“A refreshing, “different” afternoon. The event was allowed to last longer than agreed on in the program, which made people to leave before the workshop was over.” (Participant 2.)

In the lack of other feedback, the potential of small scale dialogues can be traced by comparing them to the original aims of Democratic Dialogue and the first applications. Traditionally AR, and especially PAR, is associated with the notion of combining research on important societal issues to democracy at the different levels of society, organizations and communities. This was the case, when Democratic Dialogue and Dialogue Conferences (Gustavsen, 1991) gained favor among the labor market partners in Finland (Kalliola \& Nakari,, 1999). In addition to the conduct of Dialogue Conferences, the workplace democracy aspect could be carried out in the many steering groups and task forces that followed the criteria of Democratic Dialogue (Gustavsen, 2001) in their work. As the aim, although not always totally successful, was to tie the PAR projects to the ongoing organizational change, the voice of all stakeholder groups could be integrated into the realization of sometimes mere survival, sometimes competition, strategies of organizations and into new, concrete steps of action. The not so successful examples come from cases where the dialogue forums have been used to dictate the decisions, or the participants have not taken a full advantage of dialogues forums (Kalliola \& Nakari, 2007). 
Positive or negative, these elements of intensive, long lasting development work with AR is missing, when a series of Dialogue Conferences complemented by other dialogue forums is shrunk to a miniature form and a random selection of participants. The participants may have difficulties in tracing their inputs in the final outcomes. Managers, or other leading actors, may indeed invite diverse stakeholders to workshops to ponder current issues, but without a joint agreement about joint development work there is no obligation to really hear the participants. This would mean that a value based tool of workplace development would turn into a tool of manipulations by offering the mere feeling of participation (Kalliola, 1999, 25).

However, the contents of the dialogues in this UCA \& UCB case show, how applying the original design of dialogue conferences, (Gustavsen \& Englestad, 1986), involving "right” participants, brings forward the experiences and future perspectives of various stakeholders, and enables to make feasible action plans. The plans and action taken is very concrete, and "mundane", compared with Shotter's (2004) 'actionable knowledge', but it is not impossible to see how, for example, the understanding and aiming towards 'flexibility' approximates towards Baburoglu and Ravn's (1992) idea of knowledge that becomes a piece of the continuously constructed reality.

On the other hand, timewise small scale dialogue workshops may serve other purposes. The participants, representing various positions, professions and organizations, often learn something worthwhile to apply individually, or to bring forward to their colleagues, absent from the workshop. Eskelinen and Leander (2008) mention idea generation, data gathering and formation of networks as outputs of a small scale dialogue workshop. The opportunity to participate on a democratic forum in the creation of new ideas may also support 
the agency and the sphere of choices of individuals (Eteläpelto, Vähäsantanen, Hökkä \& Paloniemi, 2013).

In the background projects of this study, in 2007, the authors were outsiders among the other members of the UC communities besides their own facing some of the problems Smith, Bratini, Chambers, Jensen and Lelaina, (2010) mention in building trust and gaining access to the communities to be partners in AR collaboration. Since in university communities the traditional tools of scientific research could not form insurmountable obstacles as in other type of local communities, a collegial bond could be established along the years and along new projects. For the time being the position of the authors approaches that of doing action research in one's own organization (Coghlans \& Brannick, 2014) along the building of regional learning structures (Eikeland, 2012).

\section{Discussion}

This case narrative continues along the lines described by Moltu (2008) who sees that PAR is usually reported as a romantic story characterized by optimism and light conquering darkness. While continuing the tradition of success stories we also want to recognize other lines of thought.

Although the central role of Democratic Dialogue in the Finnish Work Conference Method and Dialogue Workshops may seem a rather radical approach, there exist far more radical approaches in the use of participation. For example, compared to the idea of dialogics as a mean of new relationship and cooperation between students, teachers and society (Freire, 1972), Democratic Dialogue appears to be just one, quite mechanical tool, in the vast array of organization development. Also, participatory applications, like small scale Dialogue Workshops, may lead to what Adams, Daudt and Nunes Ramos 
(2016) call non-liberal view of democracy. However, in the Finnish organizational context, this type of pursuits may be even now be rejected by the management.

Management may not think that while it is almost impossible to give "from above” implementation orders that would not give any leeway, free space for discretion, participatory applications to use this leeway could be productive for all the stakeholders. This would mean a real ownership of the development process at the lowest organizational levels where the new action, ordered by the management, is supposed to take place. Along the emerging entrepreneurial universities (Sam \& van der Sidje, 2014) also the former collegial leadership is turning towards managerial models, that may, or may not, contain participatory characteristics. Participatory approaches could be useful as our case shows.

Flexible, and at the same time innovative, universities seem to be a core tool in balancing the conflict of studying and working in adult students' lives. It seems that in the future new work friendly practices will form an integral part of the university strategies. Current change drivers, technology and global competition, force them, as other national, regional and local actors to combine their efforts. Assumingly various actors will continue to deploy development projects and there will come new opportunities to exercise learnings from participatory approaches.

\section{References}


Adams, T., Daudt, P., \& Nunes Ramos, C. (2016). Book Review: Action research and democracy from the Scandinavian perspective. International Journal of Action Research, 12, 315-324.

Alasoini, T. (2008). Building better programmes: learning networks in the promotion of workplace innovation. International Journal of Action Research, 4, 62-89.

Ansela, M., Haapaniemi, T. \& Voutilainen, U. (2005). HOPS eää - Yliopistoopiskelijan henkilökohtaisen opintosuunnitelman määritelmiä. In R. JakkuSihvonen (Ed.) Uudenlaisia maistereita. Opetus 2000. Kasvatusalan koulutuksen kehittämislinjoja. (pp. 87-105). Jyväskylä: PS-Kustannus.

Baburoglu, O. N. \& Ravn. I. (1992). Normative action research. Organization Studies. 13, 19-34.

Brooks, R. \& Everett, G. (2009) Post-graduation reflections on the value of a degree, British Educational Research Journal, 35, 333-349.

Coghlan, D. \& Brannick, T. (2014). Doing Action Research in Your Own Organization. $4^{\text {th }}$ edition. Los Angeles, CA: Sage.

Eikeland, O. (2012). Action research and organisational learning: a Norwegian approach to doing action research in complex organisations. Educational Action Research, 20, 267-290.

Elden, M. (1983). Democratization and participative research in developing local theory. Journal of Occupational Behaviour, 4, 21-33. 
Eskelinen, O. \& Leander, A. (2009) “Paremmaksi Poriksi” - näkökulmia kaupungin turvallisuuskysymyksiin: raportti tutkivasta työpajasta 9.2.2008. Tampereen yliopiston Porin yksikön julkaisuja 3. Pori: Tampereen yliopisto.

Eteläpelto, A., Vähäsantanen, K., Hökkä, P. \& Paloniemi, S. (2013). 'What is agency? Conceptualizing professional agency at work', Educational Research Review, 10, 45-65.

Freire, P. (1972). The Pedagogy of the Oppressed. (Originally Pedagogia do opprimado, translated by Myra Bergman Ramos.) Harmondsworth: Benguin.

Gensby, U. (2014). Assessing the Present in Perspective of the Past: Experiences from a Chronicle Workshop on Company-Level Work Disability Management. Nordic Journal of Working Life Studies 4(2): 85-115.

Retrieved from http://rossy.ruc.dk/ojs/index.php/njwls/article/view/386672041

Gustavsen, B. (1991). The LOM Program: A Network-Based Strategy for Organization Development in Sweden. In Woodman, R. W. \& Pasmore, W. A. (Eds.) Research in Organizational Change and Development. Volume 5. (pp. 285-315).Greenwich, Conn./London: JAI Press.

Gustavsen, B. (2001). Theory and practice: The mediating discourse. In P. Reason, P. \&H. Bradbury (eds.) Handbook of Action Research, Participative Inquiry and Practice. London/Thousand Oaks, CA/New Delhi: Sage. 17-26. 
Gustavsen, B. \& Engelstad, P. H. (1986). The Design of Conferences and the Evolving Role of Democratic Dialogue in Changing Working Life. Human Relations 39, 101-115.

Kalliola, S. (1999). Promoting employee participation in municipal organizations: the role of the action researcher. In S. Kalliola \& R. Nakari, R. (eds.) Resources for renewal: a participatory approach to the modernization of municipal organizations in Finland. Dialogues on Work and Innovation 10. (pp. 15-27) Amsterdam/Philadelphia: John Benjamins.

Kalliola, S. (2009) Learning along with participatory action research - A Finnish Perspective. International Journal of Action Research, 5, 289-321.

Kalliola, S. \& Nakari, R. (1999). Resources for renewal: a participatory approach to the modernization of municipal organizations in Finland. Dialogues on Work and Innovation 10. Amsterdam/Philadelphia: John Benjamins.

Kalliola, S. \& Nakari, R. (2007). Renewing occupational cultures - Bridging boundaries in learning spaces. International Journal of Educational Research 46, 190-203.

Kalliola, S., Nakari, R. \& Pesonen, I. (2006). Learning to make changes: democratic dialogue in action. Journal of Workplace Learning, 18, 464-477.

Kauppinen, I. (2012). Towards transnational academic capitalism. Higher Education, 64, 543-556.

Keppell, M. (2014). Personalised Learning Strategies for Higher Education. 
University of Southern Queensland, USQePrints. Retrieved from http://www.eprints.usq.edu.au/25679/1/Keppell_2014.pdf

Kukulska-Hulme, A. (2012). How should the higher education workforce adapt to advancements in technology for teaching and learning? The Internet and Higher Education, 15, 247-254.

Laki sosiaalihuollon ammattihenkilöistä 817 /2015 [Act on Social Welfare Professionals]

Lewin, K. (1948). Action Research and Minority Problems. In Resolving Social Conflicts. Selected papers on group dynamics. Edited by Gertrud Weiss Lewin. (pp. 201-2016) New York: Harper \& Brothers.

Mikkonen, J., Lavikainen, E. \& Saari, J. (2013). Monituloiset. Korkeakouluopiskelijoiden tulolähteet ja kokemus toimeentulosta erilaisissa elämäntilanteissa. Opiskelun ja koulutuksen tutkimussäätiö Otus 40. Otus: Helsinki.

Moltu, B. (2008). Satiric and Romantic Stories about Organizational Change. Actor Network Theory and Action Research. International Journal of Action Research. 4, 155-179.

Mäkinen, J., Olkinuora, E. \& Lonka, K. (2004). Students at risk: Students' general study orientations and abandoning/prolonging the course of studies. Higher Education 48,173-188. 
Niemelä, J. (2014). Opiskelua työn ja perheen ristipaineessa vai siivittämänä? Työelämän tutkimus 12, 137-156.

OECD Family database www.oecd.org/social/family/databaseOECD - Social Policy Division - Directorate of Employment, Labour and Social Affairs. LMF2.4: Family-Friendly Workplace Practices. Last updated 19/09/2014.

O'Lawrence, H. (2007). An Overview of the Influences of Distance Learning on Adult Learners. Journal of Education and Human Development, 1(1). Retrieved from http://www.scientificjournals.org/journals2007/articles/1041.htm

Opetus- ja kulttuuriministeriön asetus yliopistojen perusrahoituksen laskentakriteereistä 182/2012/ [Decree by the Ministry of Education and Culture on the criteria for allocation of the basic funding to the universities]

Reason, P. \& Bradbury. P. (eds.) (2001). Handbook of Action Research, Participative Inquiry and Practice. London/Thousand Oaks, CA/New Delhi: Sage.

Saari, J., Mikkonen, J. \& Vieno, A. (2013): ”Löytöretkiä tuntemattomalle mantereelle. Yliopisto-opiskelijoiden opiskeluaikainen työssäkäynti ja tulevaisuusodotukset.” Työpoliittinen aikakauskirja, 2, 44-56.

Salonen, M. \& Suntila, J. (2008). Hyvinkö pyyhkii? Tutkimus Porin yliopistokeskuksen opiskelijoiden hyvinvoinnista. Tampereen yliopiston Porin yksikön julkaisuja 2. Pori: Tampereen yliopisto. 
Sam, C. \& van der Sijde, P. (2014). Understanding the concept of the entrepreneurial university from the perspective of higher education models. Higher Education, 68, 891-908. DOI:1007/s10734-014-9750-0.

Shotter, J. (2004). Expressing and Legitimating ‘actionable knowledge’ from within 'the moment of acting'. Concepts and Transformation 9, 205-229.

Smith, L., Bratini, L., Chambers, D.-A., Jensen, R. V. \& LeLaina, R. (2010). Between idealism and reality: meeting the challenges of participatory action research. Action Research. Published online 30 June 2010. DOI: 10.1177/1476750310366043.

Tomlinson, M. (2007). Graduate employability and student attitudes and orientations to the labour market. Journal of Education and Work, 20, 285-304.

University Consortia (2013). Energy and inspiration. From ideas to innovation. Mikkeli: University Consortia of Finland.

Weick, K. E. (1995) Sensemaking in organizations. Thousand Oaks, CA: Sage.

Ylijoki, O.-H. \& Mäntylä, H. (2003). Conflicting Time Perspectives in Academic Work. Time \& Society 12, 55-78. doi: 10.1177/0961463X0301200136

\section{About the authors}

Ossi Eskelinen (DrSocSc, social policy) has made a long career in a variety of teaching positions, including practical training and, continuing education. He has also served as Assistant Professor of Social Policy at the University of Tampere, University Consortium of Pori. His research themes have been Housing Policy, Environment Policy, Criminal Policy and 
Entrepreneurship of the Academic Persons. Currently he works as University Lecturer in areas of students' employability and evaluation. He has published about victim-offender mediation with juvenile offenders in English by Springer.

E-mail: Ossi.Eskelinen@uta.fi

Satu Kalliola (DrSocSc, social psychology) is Professor Emerita in Social Policy (University of Tampere, University Consortium of Pori), who has practiced Action Research since the early 1990s, mainly among municipal organizations. Her research interest include human resource management, labor-management cooperation and the role of trade unions in the organizational development issues. Her publications in English include edited books on workplace development and articles for example in Economic and Industrial Democracy, Journal of Workplace Learning and International Journal of Educational Research. E-mail: Satu.Kalliola@uta.fi

Jukka Niemelä (DrSocSc, sociology) has served as a teacher of Economic Sociology at the University of Turku and Associate Professor of Sociology University of Tampere, University Consortium of Pori. Currently he focuses on the issues of regional and local unemployment as Senior Researcher. He has published in English for example about team organization and outsourcing as experienced by the staff.

E-mail: Jukka.Niemela@uta.fi

Postal Address:

University of Tampere, Faculty of Social Sciences, University

Consortium of Pori

PO Box 181, 28101 Pori, Finland 